DOI: https://doi.org/10.15407/kvt205.03.070

UDC $577.169 ; 616.1-616.7$

DANILOVA V.A. ${ }^{1}$,

Senior Lecturer of the Biomedical Engineering Department

ORCID: 0000-0003-3009-6421

e-mail:valnaa@ukr.net

SHLYKOV V.V. ${ }^{\mathbf{1}}$, DSc (Engineering), Associate Professor, Head of the Biomedical Engineering Department

ORCID: 0000-0001-8836-4658

e-mail: v.shlykov@kpi.ua

DUBKO A.G. ${ }^{2}$, PhD (Engineering), Associate Professor,

Researcher of Department of Welding and Related

Technologies in Medicine and Ecology

ORCID: 0000-0001-6070-3945

e-mail: ndreyies17@gmail.com

${ }^{1}$ National Technical University of Ukraine "Igor Sikorsky Kyiv Polytechnic Institute" 37, Peremogy av., Kyiv, 03056, Ukraine

2 "E.O. Paton Electric Welding Institute"

11, Kazimir Malevich str., Kyiv, 03150, Ukraine,

\title{
DETERMINATION OF INFLUENCE PARAMETERS OF HIGH FREQUENCY CURRENT ON LIVING TISSUES
}

Introduction. High-frequency electric welding of biological tissues is an effective method of treatment in surgery. This is an electrosurgical method that minimizes the possibility of the destructive effect of electric current on soft living tissues. The welding method is widely used in general surgery for joining soft tissues where a weld is created when a high frequency electric current is passed through the tissue. With this method, it is possible to carry out serious operations, such as welding of liver tissue, retina, resection of tumor tissue and many other operations. For operations in surgery, it is important to know the optimal parameters of HF-welding, such as welding temperature, mechanical stress on tissues, welding time and voltage.

The purpose of the paper is to determinatethe optimal conditions for high-frequency welding of living tissues, such as welding temperature, mechanical stress on tissues, welding time and voltage. To determine these parameters, the liver tissue fusion was simulated in the Sinda and Comsol software.

Results. As a result of modeling and research, model dependencies were obtained that determine the optimal parameters of high-frequency welding for performing surgical operations for resection and welding of liver tissue. In the place of direct contact of the electrodes with the tissue, the temperature does not exceed $+70^{\circ} \mathrm{C}$, and at a distance of $2 \mathrm{~mm}$ in the adjacent tissues does not exceed $+50^{\circ} \mathrm{C}$, which provides a tissue-preserving electrosurgical effect. 
Conclusions. The studies have shown that mathematical modeling of heating biological tissue by a split electrode, through which a high-frequency current passes, practically coincides with a real experiment. The optimal conditions for high-frequency welding of living tissues obtained as a result of modeling, such as welding temperature and welding time make it possible to reduce the recovery period after applying the HF-welding method by choosing the optimal coagulation modes.

Keywords: welding of biological tissues, mathematical modeling, temperature, liver, surgery, modeling in Sinda, modeling in Comsol.

\section{INTRODUCTION}

The use of welding of living tissue for hemostasis in surgical operations reduces blood loss, cost and time of surgery [1-3]. The use of live tissue fusion for hemostasis in surgical procedures reduces blood loss, cost and time of surgery. For hemostasis, bipolar forceps and clamps are used. Monopolar electrodes are used for welding and hemostasis in ophthalmology. Instruments with split electrodes are used for bloodless tissue cutting, hemostasis of the surface of wounds, and in thoracic surgery. With the help of special clamps with narrow electrodes and welding modes, bloodless tissue cutting is possible with simultaneous hemostasis and an increase in the ablasticity of the surgical operation.

The voltage and duration of welding are automatically changed depending on the condition and thickness of the fabric, the degree of contamination of the electrodes and the force of their compression. The relative impedance value is used as information about the state of the tissue Z. At the start of welding, the impedance drops to the $Z_{\min }$ value due to heating of the fluid in the tissue, and then begins to rise due to protein coagulation and tissue drying. The highfrequency welding control system by regulating the voltage stabilizes the impedance at the level $(1,3-1,5) * Z_{\min }$ (Fig. 1) [4].

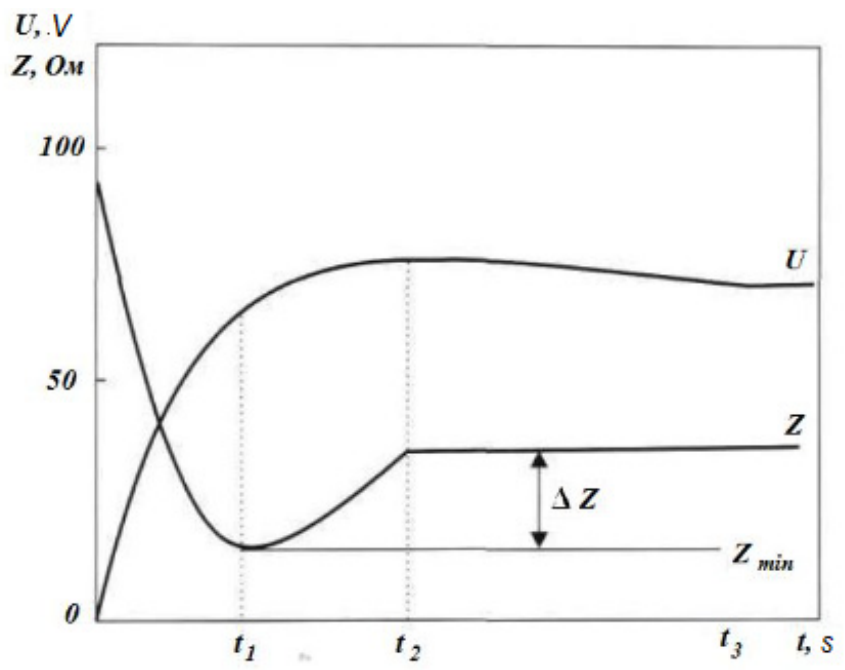

Fig. 1. The dependence of voltage and impedance $Z_{m i r}$ with automatic control of welding: $t_{1}, t_{2}, t_{3}-$ high-frequency heating stages relative to impedance value. 
The operating modes of electro-welding exposure in the physiological range, worked out in the course of many years of clinical practice, made it possible to register structural events at the molecular and nanostructural levels. In particular, it was shown that during high-frequency welding, more labile globular proteins undergo thermal denaturation: an increase in temperature causes a structural transition of the "globulecoil" type, resulting in the formation of glue-like substances. The advantage of the method of high-frequency (HF) welding of living tissues is that it is possible to avoid the presence of foreign material and problems of immune incompatibility [5].

\section{PROBLEM STATEMENT}

On the basis of the obtained experimental and clinical data [1-5], the ability of tissue exposed to high-frequency welding to maintain its viability, restore physiological properties and functions through regeneration processes has been demonstrated.

In the study [5], it was shown that when an electric current passes through the tissue between the electrodes, the temperature of the tissue in the center of the welded joint rapidly rises to a temperature $60-70^{\circ} \mathrm{C}$ coagulation of proteins and denaturation of cells, and then, after turning off the current, the temperature gradually decreases exponentially to the initial values $15-20^{\circ} \mathrm{C}$ (Fig. 2).

To find the optimal conditions for HF-welding of living tissue, it is important to know the optimum welding parameters such as welding temperature, mechanical stress on tissue, welding time and voltage. To determine these parameters, the welding of biological tissues was simulated in special software. The simulation was carried out by the finite element method in the Sinda and Comsol software environments. [6, 7].

To simulate the welding of biological tissues, the real values of biological tissues (Young's modulus, Poisson's ratio) and electrode characteristics (material, electrical and thermal conductivity) were used. After the selection of materials, research was carried out. In the model, the current was transmitted through biological tissue when the electrode interacted with the tissue. A certain pressing force was applied to the electrode. To find the optimal welding parameters during the experiment, a constant value of the force applied to the electrode, the welding time and the electric voltage were set. The safe welding temperature is $60-90^{\circ} \mathrm{C}$.

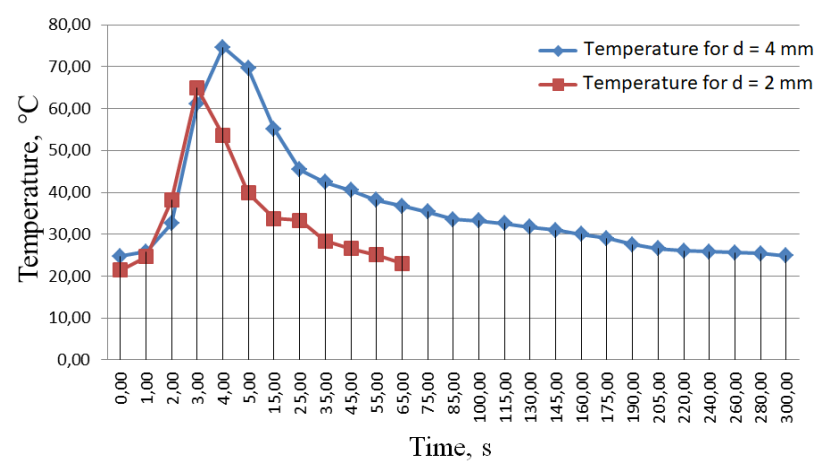

Fig. 2. Temperature change in muscle tissue with a thickness of $2 \mathrm{~mm}$ and $4 \mathrm{~mm}$ during HF-welding and cooling relative to the initial temperature $15^{\circ} \mathrm{C}$. 
To find the optimal temperature, a sample of the study parameters was carried out. As a result, model dependencies were obtained that can determine the optimal parameters of HF-welding.

\section{THE PURPOSE STUDY}

A model of welding in liver tissues was built in the environment of Sinda and Comsol. For welding it is necessary to find safe conditions of welding process and to define optimum parameters. Thanks to the Sinda and Comsol software, it is possible to perform experiments without the use of clinical experiments.

The study of the optimal parameters of HF-welding of living tissues will allow surgery in the future to non-invasively control the temperature of nearby tissues and determine the quality of the weld.

The purpose of the paper is to determinatethe optimal conditions for highfrequency welding of living tissues, such as welding temperature, mechanical stress on tissues, welding time and voltage. To determine these parameters, the liver tissue fusion was simulated in the Sinda and Comsol software.

\section{METHODS AND MEASURES OF THE RESEARCH}

Liver tissue temperatures during high frequency welding are measured using a thermograph FLIR ThermaCAM E300, which has temperature sensitivity $0,1^{\circ} \mathrm{C}$ and measurement error $\pm 1 \%$ of the measurement range. The technical capabilities of the thermograph allow to determine the minimum temperature difference between the nearby tissues from $0,5^{\circ} \mathrm{C}$ to $10^{\circ} \mathrm{C}$.

Finite element modeling was performed in the Sinda and Comsol programs. The maximum welding temperature is $90{ }^{\circ} \mathrm{C}$. To simulate the process of highfrequency welding, a constant value of the application of force to the electrode, the welding time and the electrical voltage between the electrodes are set.

To determine the optimal temperature of high-frequency welding of liver muscle tissue, the study parameters (current in the electrode, voltage, tissue temperature) were selected, which allows to determine the optimal welding parameters.

\section{RESEARCH OF TEMPERATURE GRADIENTS ON THE LIVER SURFACE}

For high-frequency welding of tissues in research and execution model used a bipolar electrosurgical instrument with a split electrode (Fig. 3), which allows to destroy the muscle tissue of the liver with an electric current while stopping bleeding.

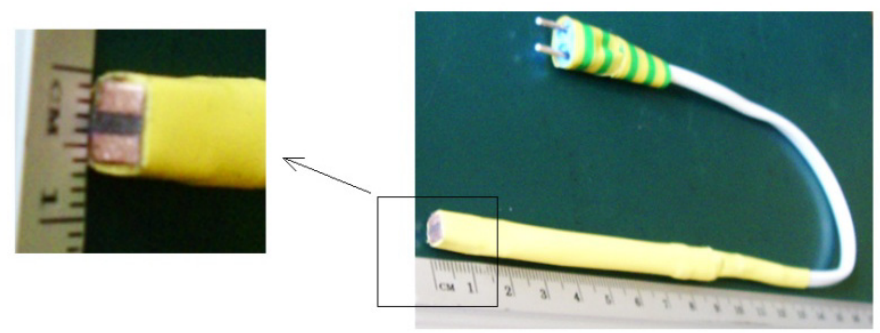

Fig. 3. A bipolar electrosurgical instrument with a split electrode 


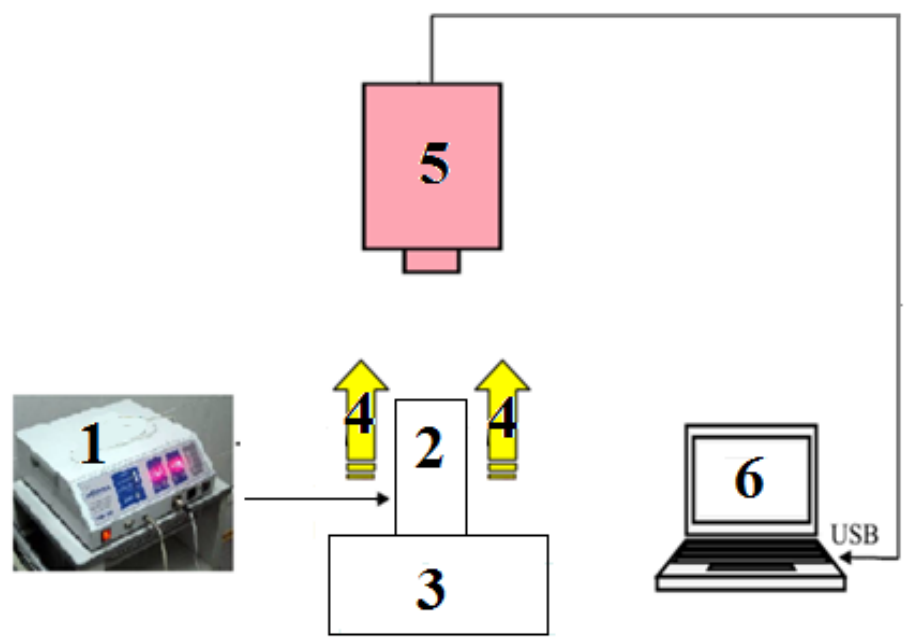

Fig. 4. Research block diagram

The block diagram of the studies performed is shown in Fig. 4. And it consists of 1 - power supply EKVZ-300 "Patonmed", 2 - bipolar electrosurgical instrument with a split electrode, 3 - research object (biological tissue), 4 infrared radiation, 5 - thermographic system based on the thermal imager ThermaCAM E300, 6 - personal computer with specialized software.

During the research, the coagulation mode was used at $75 \%$ of the power of the EKVZ-300 apparatus. The object of research is the temperature change in tissues isolated porcine liver (Fig.5).

Non-invasive temperature control in liver tissues was performed with a thermograph ThermaCAM E300 in the mode of ablation by high-frequency current using the EKVZ-300 "Patonmed" apparatus. The temperature of the tissues between the electrodes was measured using a thermography system. The spectral range of the infrared thermograph was from $7.5 \mu \mathrm{m}$ to $13 \mu \mathrm{m}$. The distance between the object and the lens of the thermograph was from $0.1 \mathrm{~m}$ to $1 \mathrm{~m}$. The temperature measurement error was no more than $\pm 2 \%$ in the temperature measuring range from $0^{\circ} \mathrm{C}$ to $80^{\circ} \mathrm{C}$, temperature sensitivity of the thermograph $0,1^{\circ} \mathrm{C}$.

The change in the temperature of liver tissue with a thickness of up to $4 \mathrm{~mm}$ in the center of application of the split electrode and in the area of nearby tissues (with a radius of up to $2 \mathrm{~mm}$ ) during high-frequency welding is shown in Figure 7.

The input data for modeling the process of heating and cooling the tissues of the isolated liver in the process of high-frequency heating are the temperature data measured with a thermal imager with a time interval of $1 \mathrm{~s}$ (Fig. 6).

Obviously, the cooling process of the tissues of the isolated liver after highfrequency welding has an exponential relationship, and thus the estimated time for re-ablation of a tissue site can be determined from the expression:

$$
\Delta t \approx 3,14 \cdot T,
$$

where $\mathrm{T} \leq 1$ is a time of high-frequency welding of a tissue section, sec. 


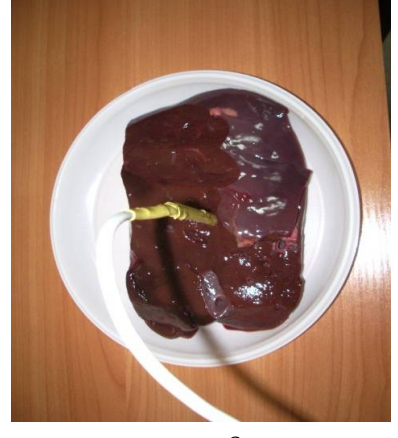

a

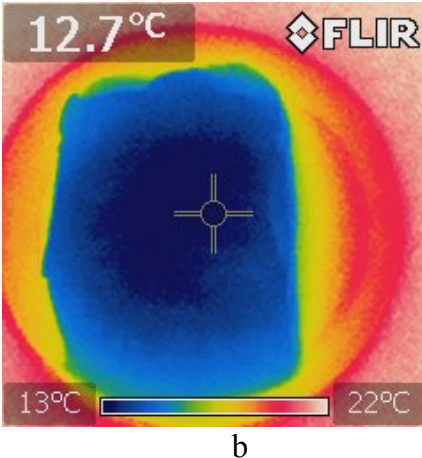

$\mathrm{b}$

Fig. 5. Object of research: a) pork liver with an installed split electrode, b) pork liver in the infrared spectrum.

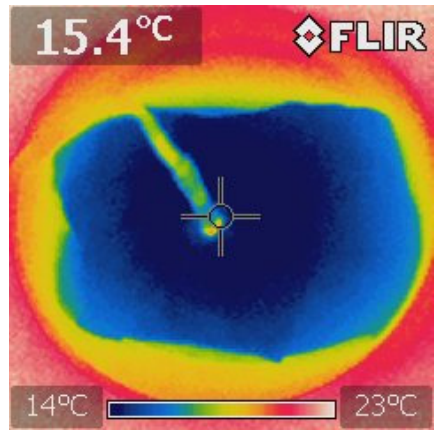

a)

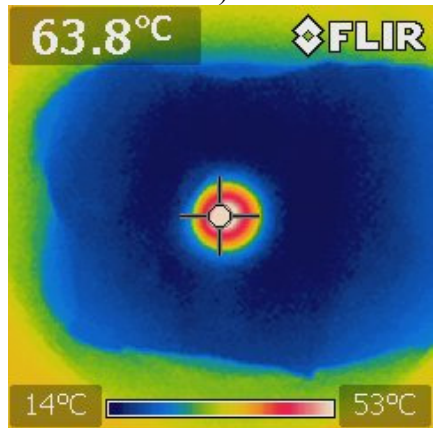

c)

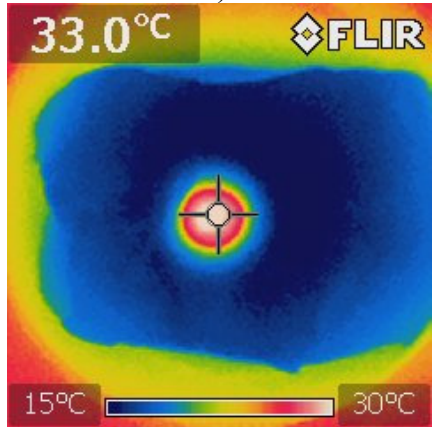

e)

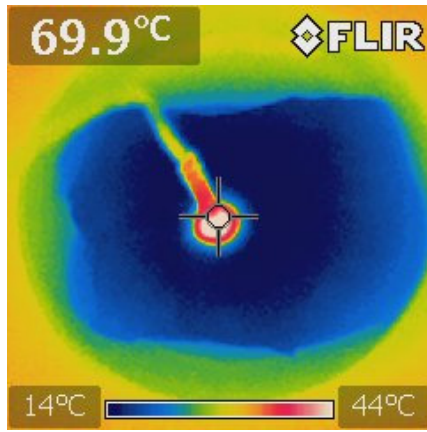

b)

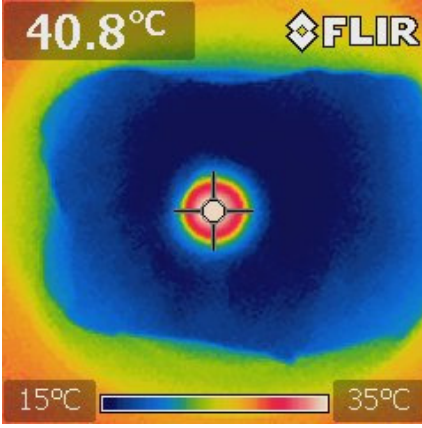

d)

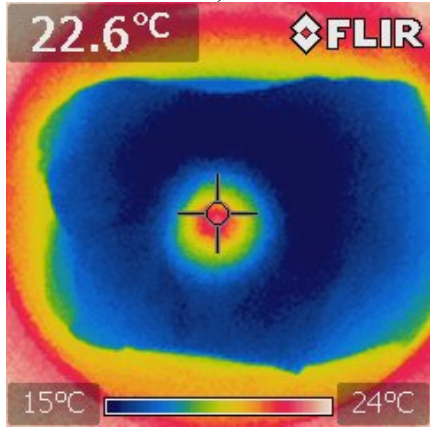

f)

Fig. 6. Pork liver in the infrared spectrum during HF-welding: temperature data with a time interval of $1 \mathrm{~s}$. 


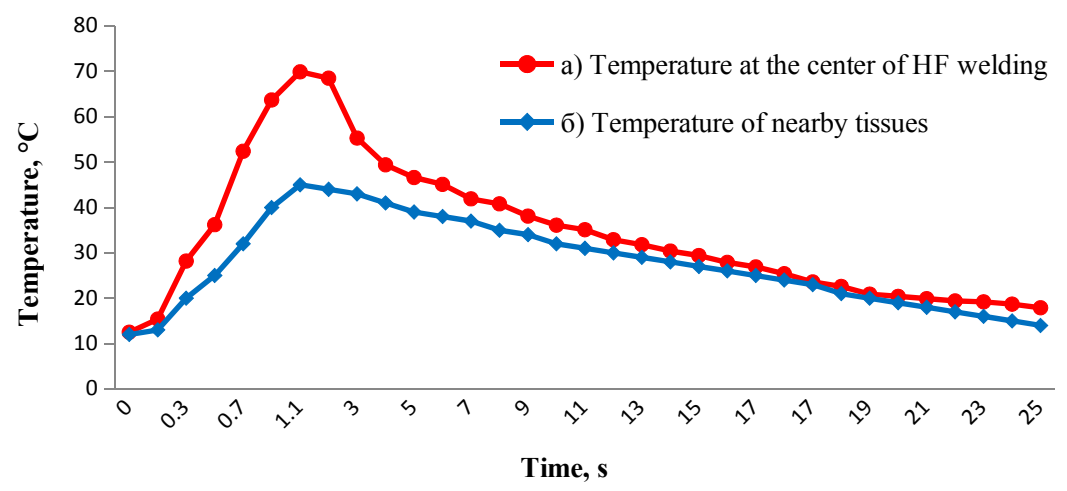

Fig. 7. Change in liver tissue temperature: a) in the center of application of the split electrode, b) in the area of nearby tissues with a radius of up to $2 \mathrm{~mm}$.

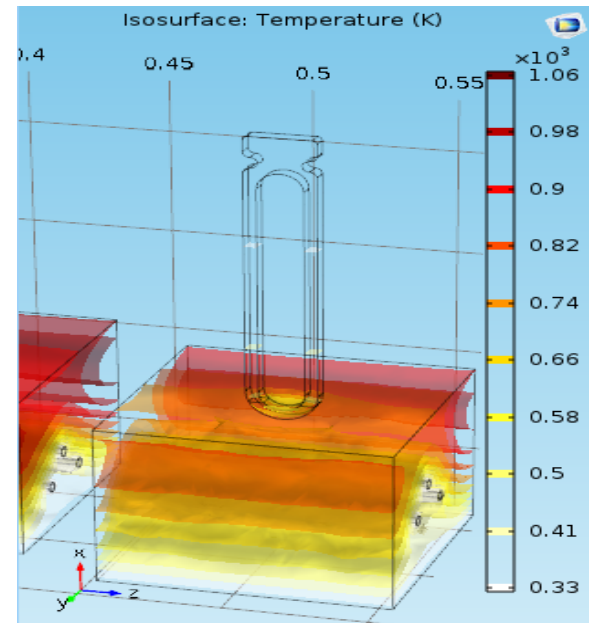

a)

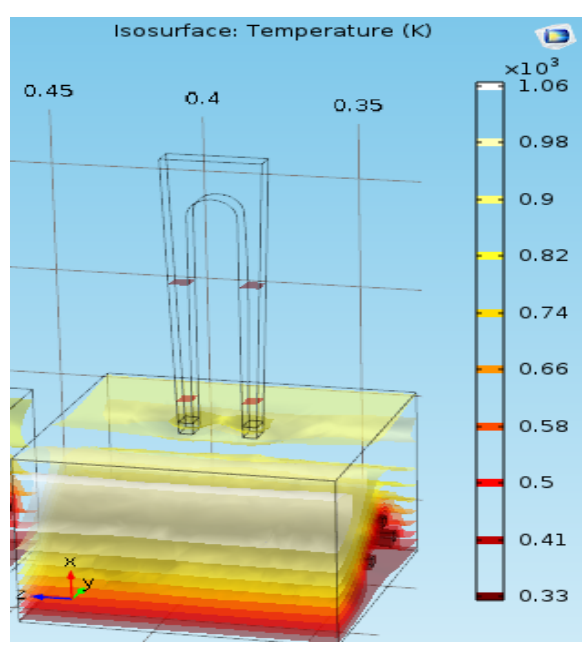

b)

Fig. 8. Model of high-frequency welding in the Comsol environment for different types of electrodes: a) model with a closed electrode, b) model with a split electrode.

In the implemented model of the high-frequency welding process, a constant value of the application of force to the electrode, the welding time and the electric voltage between the electrodes were set. The model in the Comsol environment is built for two types of electrodes: a model with a closed electrode and a model with a split electrode (Fig. 8).

The distribution of high-frequency current in the electrodes of electrosurgical instruments has been shown in previous studies $[8,9]$. Mathematical modeling of the stationary distribution of temperature fields in a two-phase medium (electrode biological tissue) at a frequency of $440 \mathrm{kHz}$ is considered in detail [10]. The presented model makes it possible to study the non-stationary distribution of the temperature field using an infrared thermograph, with a tissue-preserving technology of welding biological tissues. 
The temperature distribution in the material is described by the thermal conductivity equation, which has the form:

$$
c \quad \frac{\partial T}{\partial t}-\nabla(k \nabla T)=Q,
$$

where $\rho$ is a density; $C$ is a specific heat; $k$ is a coefficient of thermal conductivity; $\rho$ is a nabla operator; $Q$ is a heating source distribution function; $T$ is a temperature; $t$ is a time.

To solve this problem of heat transfer, first of all, it is necessary to solve the electromagnetic problem and, as a result, find $Q$-distribution function of heating sources.

From Maxwell's equations [11] follows an equation that describes electromagnetic processes in conducting media.

$$
-\nabla\left(\frac{1}{\mu} \nabla E\right)+\left(j \omega \sigma-\omega^{2} \varepsilon\right) E=0,
$$

where $E$ is a electric field strength; $\mu$ is a magnetic permeability of a conductive medium; $j$ is a imaginary unit; $\omega$ is a angular frequency; $\sigma$ is a specific conductivity; $\varepsilon$ is a dielectric constant of the conducting medium.

Equation (2) makes it possible to determine the electric field strength $E$ and the distribution of heating sources $Q$ when a high-frequency current flows in conducting media:

$$
Q=\sigma \cdot E^{2} .
$$

In clinical practice, in order for the restoration of the physiological functions of an organ to proceed quickly enough and not to entail complications, the thermal input should be minimal, but sufficient for the formation of a high-quality compound [12].

\section{RESULTS OF MODELING FOR HIGH-FREQUENCY HEATING OF TISSUES}

To solve the differential equation of heat conduction in the MSC Sinda system, the thermal network method is used (TNM - Thermal Network Method) [13], wherein the thermal conductivity of the system of equations is represented as a cell — centered nodes and resistances between the nodes using the method of finite differences (Fig. 9).

Application of the TNM method to the heat equation gives the following discrete form of the equation [14]:

$$
\frac{\partial T_{i}}{\partial t} \approx \frac{1}{(m \cdot c)_{i}}\left[\sum_{j=1}^{N} C_{i, j}\left(T_{j}-T_{i}\right)+\sum_{j=1}^{N} R_{i, j}\left(T_{j}^{4}-T_{i}^{4}\right)\right], \quad i=1, \ldots, N
$$

where $(m \cdot c)_{I}$ is a node capacity in the $I$ is a node, $N$ is the total number of diffusion nodes of the network, $R_{i, j}$ is athermal radiation from the resistance between the nodes $i$ and $j, C_{i, j}$ is the capacity of the linear conductor between the nodes $i$ and $j$. 
The MSC Sinda system allows to perform thermal analysis of the model and all types of heat transfer: thermal conductivity, free or forced convection, advection, radiation, as well as to take into account such effects as ablation and thermal contact between nearby tissue layers (Fig. 10).

In high-frequency welding of liver tissues, more labile globular proteins undergo thermal denaturation - an increase in temperature causes a structural transition, as a result of which adhesive-like substances are formed.

The course of thermal denaturation processes depends on the temperature distribution in the depth of the fabric, which can be determined from the results of modeling high-frequency welding in Comsol (Fig. 11).

In the model, the heat transfer coefficient for free convection in the surface layer of the fabric corresponds to the natural model of laminar flow convection (ID $=701$ for Convection Correlation Lib MSC Sinda) through the surface of the object of study with a characteristic length.

As a result, the nature of the process of heating the surface layer of liver tissue during high-frequency welding has the form shown in Figure 12.
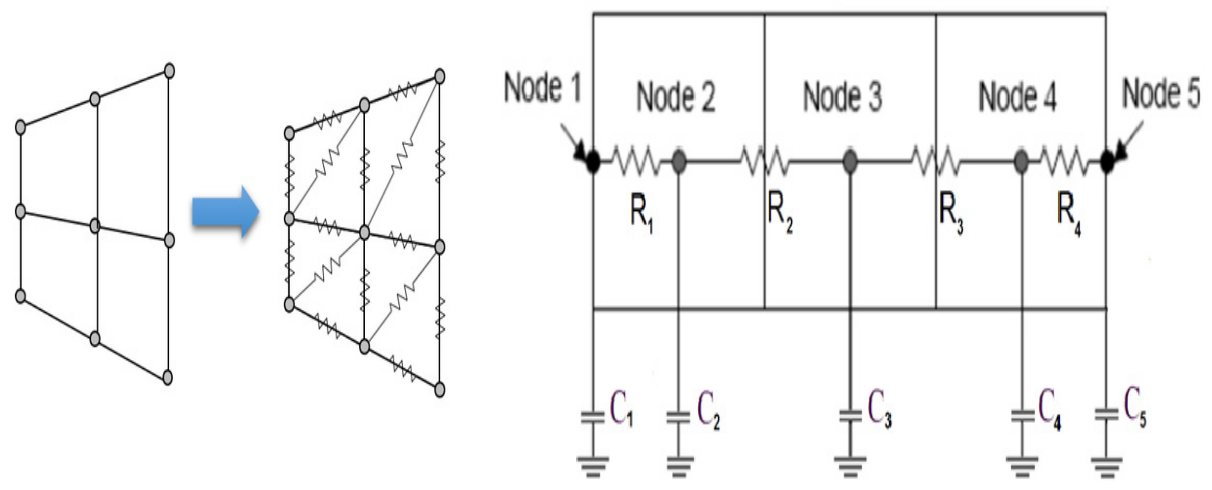

Fig. 9. Thermal RC-network based on the equivalent electrical circuit:

Node - network nodes,

$\mathrm{R}$ - resistances equivalent to thermal radiation,

$\mathrm{C}$ - capacity equivalent to thermal conductivity between network nodes. 


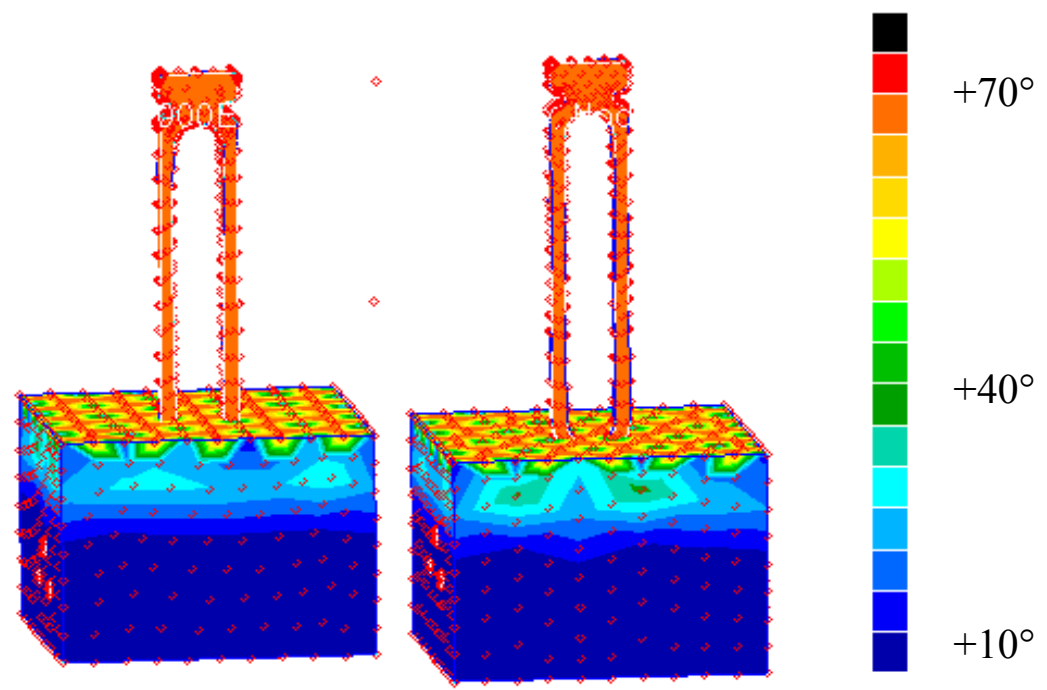

Fig. 10. Model of high-frequency welding process in MSC Sinda system

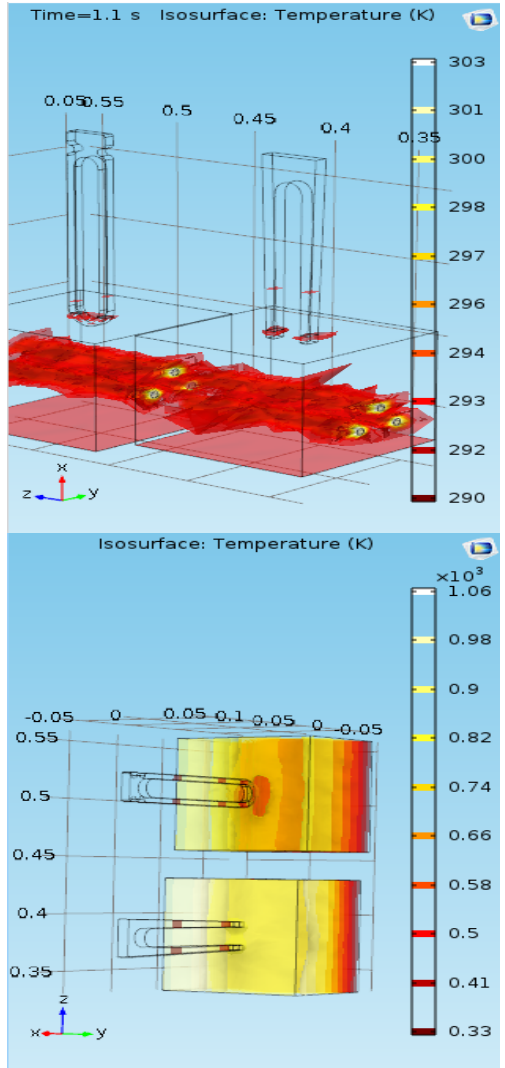

a)

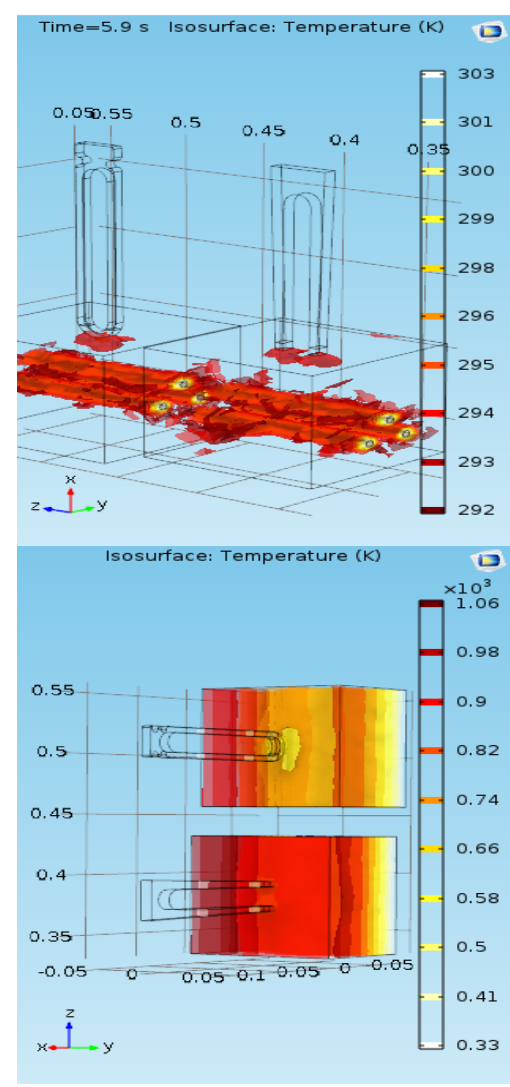

b)

Fig. 11. Model of temperature distribution in tissue in Comsol: a) after $1.0 \mathrm{~s}$. at a temperature of $+70^{\circ} \mathrm{C}$ on the surface, b) after $6.0 \mathrm{~s}$. at a temperature of $+70{ }^{\circ} \mathrm{C}$ at a depth of $4 \mathrm{~mm}$. 


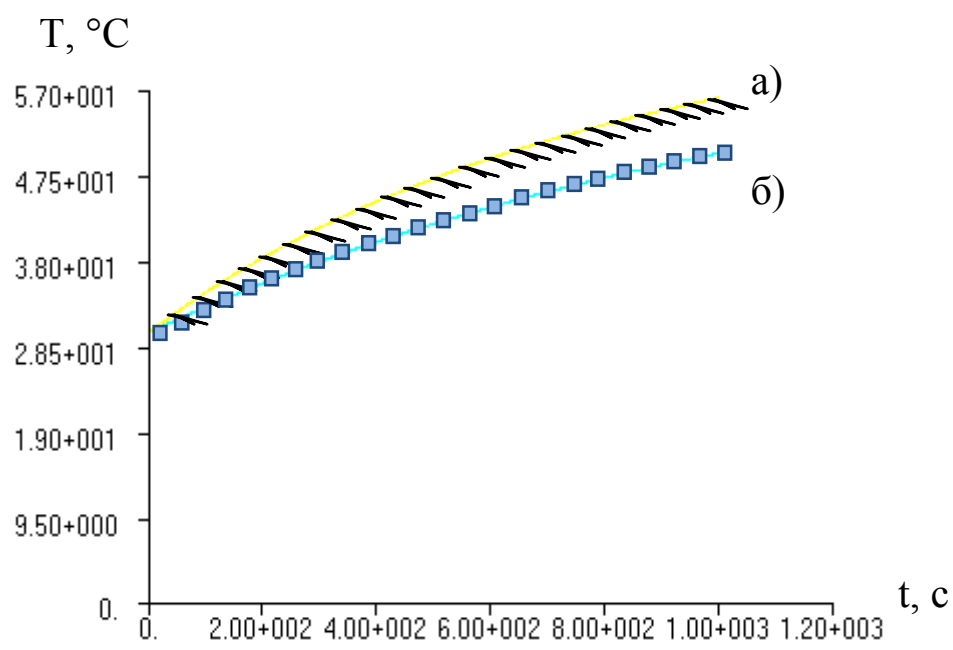

Fig. 12. The nature of the process of heating the surface layer of the fabric during high-frequency welding: a) on the surface, b) at a depth of $4 \mathrm{~mm}$.

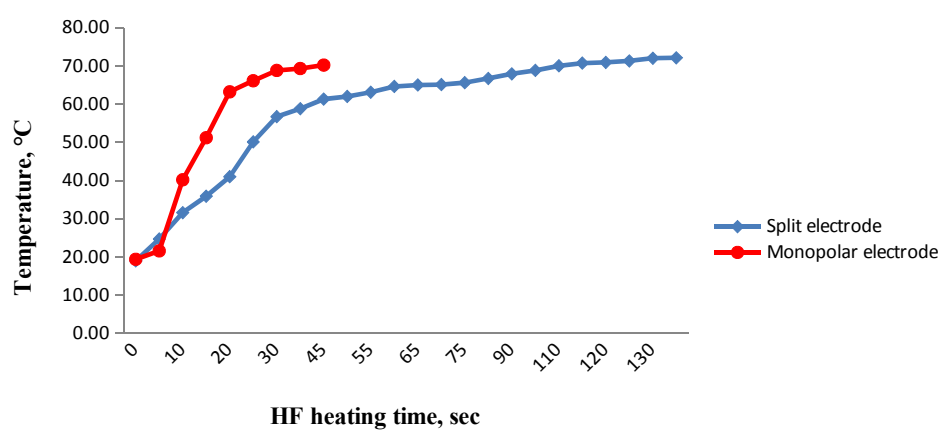

Fig. 13. Temperature change in liver tissue based on Comsol models for temperature distribution in the field of application of the welding electrode: a) monopolar electrode, b) split electrode.

The dynamics of the change in the temperature of the liver tissue, obtained on the basis of the model of temperature distribution in the software Comsol in the field of application of the monopolar and split electrode for the high-frequency welding process is presented in Figure 13.In the place of direct contact of the electrodes with the tissue, the temperature does not exceed $+70^{\circ} \mathrm{C}$, and at a distance of $2 \mathrm{~mm}$ in the adjacent tissues does not exceed $+50^{\circ} \mathrm{C}$, which provides a tissue-preserving electrosurgical effect.

At high-frequency welding of living tissues both by a monopolar electrode, and the split electrode full sealing of connection of fabric (weld) and asepsis of an operating field due to bloodless cutting and welding by high-frequency current, preservation of a hemostasis of a wound surface is provided.

The parameters of the welding mode are set and maintained based on the results of identification of the type of fabric, its condition etc. As a result of the use of coagulation modes, in this study mode $1-100 \%$ power and mode $3-50 \%$ power, the optimal effect of HF-current on the operated tissue is achieved, which ultimately leads to a high quality connection. 


\section{CONCLUSIONS}

Thus, the study of non-stationary temperature field distribution using an infrared thermograph is an effective example of the use of tissue-preserving HF-technology welding of biological tissues in surgery.

The results of modeling the temperature distribution during electrosurgical exposure for the gentle mode of high-frequency heating of the liver tissue coincide with the experimental results and show that the maximum temperature at the place of direct contact of the electrodes with the tissue does not exceed $+70^{\circ} \mathrm{C}$, and at a distance of $2 \mathrm{~mm}$ in the adjacent tissues does not exceed $+50^{\circ} \mathrm{C}$. The temperatures reached in the process of high-frequency heating exclude overcoagulation (overheating) of tissues, which provides a tissue-preserving electrosurgical effect on soft biological tissues.

Studies have shown that the mathematical modeling of the heating of biological tissue by a split electrode, through which a high-frequency current passes, practically coincides with a real experiment. This approach will further allow the development of new electrosurgical instruments for specific surgical operations on different types of tissues.

The proposed method of non-invasive temperature control of soft biological tissues allows increasing the efficiency of treatment of surgical patients by determining the optimal parameters of high-frequency welding based on modeling of heat transfer processes during welding of living tissues.

The optimal conditions for high-frequency welding of living tissues, such as welding temperature, welding time and stress, obtained as a result of thermographic studies and modeling, allow reducing the recovery period after the application of the highfrequency welding method by choosing the optimal coagulation regimes.

\section{REFERENCES}

1. Lebedev, A.V., Dubko, A.G. Use of Electric Welding of Living Tissues in Surgery (review). Biomed Eng. 2020, 54, pp.73-78. https://doi.org/10.1007/s10527-020-09977-3.

2. Molotkovets, V.Y., Medvediev, V.V., Korsak, A.V. et al. Restoration of the Integrity of a Transected Peripheral Nerve with the Use of an Electric Welding Technology. Neurophysiology. 2020, 52, pp. 31-42 (2020). https://doi.org/10.1007/s11062-020-09848-3.

3. Vazina, A.A., Vasilieva, A.A., Lanina, N.F. et al. Study of molecular and nanostructural dynamics of biological tissues under the influence of high-frequency electrosurgical welding. Bull. Russ. Acad. Sci. Phys. 2013, 77, pp.146-150. https://doi.org/10.3103/S1062873813020391.

4. Paton B.E., Lebedev V.K., Lebedev A.V. et al. Method for welding soft tissues of animals and humans: RU229417. Application number: 2003135514/14. Publication date: 2007.02.27 (In Russian)

5. Shlykov V., Kotovskyi V., Dubko A., Visniakov N., Šešok A. Temperature monitoring for high frequency welding of soft biological tissues: A prospective study. Technology and Health Care, 2019, vol. Pre-press, no. April, pp. 1-7.

6. Astrium. SINDA User Manual, ver. 3.2., 2003, 895 p.

7. COMSOL Multiphysics Reference Manual, ver.5.5, 2019, $1742 \mathrm{p}$.

8. Sydorets, V., Dubko, A. The current distribution in the electrodes of electrosurgical instruments during welding of biological tissues. Eastern-European Journal of Enterprise Technologies. 2015, 3(5), pp. 24-28.

9. Sydorets, V., Lebedev, A., Dubko, A. Mathematical modeling of the current density distribution in a high-frequency electrosurgery. Proceedings - 2015 16th International Conference on Computational Problems of Electrical Engineering, CPEE, 2015, pp. 215-217. 
10. Dubko, A., Sydorets, V., Bondarenko, O. Simulation of the Temperature Distribution with High-Frequency Electrosurgical Heating. $38^{\text {th }}$ International Conference on Electronics and Nanotechnology (ELNANO - 2018), Kyiv, Ukraine. 2018, p. 394-397.

11. Zoya Popovic, Branko D. Popovic. Introductory Engineering Electromagnetics. Prentice Hall, $1999,548 \mathrm{p}$.

12. Vazina, A.A., Lanina, G. S. Marinsky et al. Influence of high-frequency electrosurgical welding on the functional stability of the structure of biological tissues. Welding of soft living tissues. Current state and development prospects: materials of the Sixth International Seminar: edited by O. N. Ivanova. Kyiv: E.O. Paton Electric Welding Institute, 2011. p. 53. (In Russian)

13. MSC Sinda 2017 User's Guide: ID DOC11364. MSC Software Corporation. 2017, 451 p.

14. Vitaliy B., Maksymenko V., Danilova A., Shlykov V. The Discrete Model for the System of the Myocardium and Coronary Vessels.KPI Science News. 2017, No 1, pp. 54-60.

Received: 05.04.2021

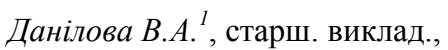
кафедра біомедичної інженерії

e-mail: valnaa@ukr.net

ORCID: 0000-0003-3009-6421

Шликов B.B. ${ }^{l}$, д-р техн. наук, доцент,

зав. кафедри біомедичної інженерії

e-mail: v.shlykov@kpi.ua

ORCID: 0000-0001-8836-4658

Дубко А.Г. ${ }^{2}$, канд. техн. наук, доцент,

наук. співроб. відд. зварювання

та спорідненихтехнологій в медицині та екології

e-mail: ndreyies17@gmail.com

ORCID: 0000-0001-6070-3945

${ }^{1}$ Національний технічний університет України

«Київський політехнічний інститут імені Ігоря Сікорського»

пр. Перемоги, 37, Київ, 03056, Україна

${ }^{2}$ Інститут електрозварювання ім. Є.О. Патона

вул. Казимира Малевича, 11, Київ, 03150, Україна

\section{ВИЗНАЧЕННЯ ПАРАМЕТРІВ ВПЛИВУ ВИСОКОЧАСТОНОГО СТРУМУ НА ЖИВІ ТКАНИНИ}

Вступ. Високочастотне електрозварювання біологічних тканин є ефективним методом лікування в хірургії. Це метод електрохірургічного впливу, який мінімізує можливість руйнівної дії електричного струму на м'які живі тканини. Метод зварювання широко використовується в загальній хірургії для з'єднання м'яких тканин, коли зварений шов виникає при проходженні електричного струму високої частоти через тканину. За допомогою цього методу можна проводити серйозні операції, такі як зварювання тканин печінки, сітківки, резекція пухлинної тканини і багато інших операцій. Для операцій в хірургії важливим $є$ знання оптимальних параметрів ВЧ-зварювання, таких як температура зварювання, механічне навантаження на тканини, час зварювання і напруга.

Метою статті $\boldsymbol{\epsilon}$ визначення оптимальних умов для високочастотного зварювання живих тканин, таких як температура зварювання, механічне навантаження на тканини, час зварювання і напруга. Для визначення цих параметрів було проведено моделювання зварювання тканин печінки в програмному забезпеченні Sinda i Comsol.

Результати. В результаті моделювання і досліджень були отримані модельні залежності, які визначають оптимальні параметри високочастотного зварювання для виконання хірургічних операцій по резекції та зварювання тканин печінки. У місці безпосереднього контакту електродів з тканиною температура не перевищує $+70^{\circ} \mathrm{C}$, і на 
відстані 2 мм в довколишніх тканинах не перевищує $+50^{\circ} \mathrm{C}$, що забезпечує нетравматичний електрохірургічний вплив.

Висновки. Дослідження показали, що математичне моделювання нагріву біологічної тканини розщепленим електродом, через який проходить струм високої частоти, практично збігається з реальним експериментом. Отримані в результаті моделювання оптимальні умови для високочастотного зварювання живих тканин, такі як температура зварювання і час зварювання, дозволяють зменшити відновний період після застосування методу ВЧ-зварювання за рахунок вибору оптимального режиму коагуляції.

Ключові слова: зварювання біологічних тканин, математичне моделювання, температура, печінка, хірургія, моделювання в Sinda, моделювання в Comsol. 